\title{
Familial Mediterranean Fever in older children
}

\author{
Semanur Özdel ${ }^{1}$, Zeynep Birsin Özçakar ${ }^{1 *}$, Seda Sahin², Mesiha Ekim ${ }^{1}$, Atilla Elhan³ ${ }^{3}$ Fatos Yalcinkaya ${ }^{1}$ \\ From 21st European Pediatric Rheumatology (PReS) Congress \\ Belgrade, Serbia. 17-21 September 2014
}

\section{Introduction}

Familial Mediterranean Fever (FMF) is an autosomal recessive disease, characterised by recurrent, self limited attacks of fever with serositis.

\section{Objectives}

The aim of this study was to compare the demographic, clinical and genetic features of FMF patients who had late onset disease to those with earlier onset during childhood period.

\section{Methods}

Files of patients who had been seen in our department (during routine follow-up visits) between January 2013 and January 2014 were retrospectively evaluated. Patients were divided into two groups according to age of disease onset (Group I: $\leq 8$ years of age; Group II: $>8$ years of age). with late onset disease have milder illness. However, more readily expression of their clinical findings in older ages yields earlier diagnosis in this group.

\section{Disclosure of interest}

None declared.

\section{Authors' details}

${ }^{1}$ Pediatric Rheumatology, Ankara University, Ankara, Turkey. ${ }^{2}$ Pediatrics, Ankara University, Ankara, Turkey. ${ }^{3}$ Biostatistics, Ankara University, Ankara, Turkey.

Published: 17 September 2014

doi:10.1186/1546-0096-12-S1-P254

Cite this article as: Özdel et al:: Familial Mediterranean Fever in older children. Pediatric Rheumatology 2014 12(Suppl 1):P254.

\section{Results}

The study group comprised 317 FMF patients (170 females, 147 males) with a mean age of $12.2 \pm 5.7$ years. There were 267 patients (84.3\%) in group I and 50 patients (15.7\%) in Group II. Median attack frequency before colchicine therapy was 24/year in Group I and 12/year in Group II $(\mathrm{p}<0,05)$. Although the frequency of majority of the clinical features did not differ between the groups, fever was seen less frequently in Group II patients $(p=0,003)$. M694V homozygosity was also less frequently detected in group II patients $(\mathrm{p}=0.022)$. Median disesase severity scores and final colchicine dosages were lower in Group II $(p<0,001 ; p=0,003)$. Median delay in diagnosis was 24 months in Group I and 12 months in Group II $(\mathrm{p}=0,002)$.

\section{Conclusion}

Only a small number of FMF patients had disease onset at older ages in childhood period. It seems that FMF patients

${ }^{1}$ Pediatric Rheumatology, Ankara University, Ankara, Turkey

Full list of author information is available at the end of the article

Submit your next manuscript to BioMed Central and take full advantage of:

- Convenient online submission

- Thorough peer review

- No space constraints or color figure charges

- Immediate publication on acceptance

- Inclusion in PubMed, CAS, Scopus and Google Scholar

- Research which is freely available for redistribution

Submit your manuscript at www.biomedcentral.com/submit
() Biomed Central
C Biomed Central

(c) 2014 Özdel et al; licensee BioMed Central Ltd. This is an Open Access article distributed under the terms of the Creative Commons Attribution License (http://creativecommons.org/licenses/by/4.0), which permits unrestricted use, distribution, and reproduction in any medium, provided the original work is properly cited. The Creative Commons Public Domain Dedication waiver (http://creativecommons.org/publicdomain/zero/1.0/) applies to the data made available in this article, unless otherwise stated. 